University of Nebraska - Lincoln

DigitalCommons@University of Nebraska - Lincoln

Journal for the Advancement of Developing

Economies

Economics Department

2012

\title{
Technology and the Export Behavior of Small, Locally- owned Firms: New Insight
}

Densil A. Williams

The University of the West Indies, densil.williams@uwimona.edu.jm

Follow this and additional works at: https://digitalcommons.unl.edu/jade

Part of the Econometrics Commons, Growth and Development Commons, International Economics Commons, Political Economy Commons, Public Economics Commons, and the Regional Economics Commons

Williams, Densil A., "Technology and the Export Behavior of Small, Locally- owned Firms: New Insight" (2012). Journal for the Advancement of Developing Economies. 15.

https://digitalcommons.unl.edu/jade/15

This Article is brought to you for free and open access by the Economics Department at DigitalCommons@University of Nebraska - Lincoln. It has been accepted for inclusion in Journal for the Advancement of Developing Economies by an authorized administrator of DigitalCommons@University of Nebraska - Lincoln. 


\title{
Technology and the Export Behavior of Small, Locally-Owned Firms: New Insight
}

\author{
Densil A. Williams \\ The University of the West Indies
}

\begin{abstract}
This paper investigates the relationship between technology and the export performance of small, locally-owned firms in the Jamaican economy. The literature argues that technology is an important variable in influencing the export performance of small firms given its technological ability to generate competitive advantage for the firm. However, the results from empirical studies are not always consistent. To investigate this issue, the paper uses survey data collected through face-to-face interviews of 92 exporters and non-exporters to estimate a logistic regression model of the firm's export behavior. The results revealed that firm size, is the most critical factor that determines export performance. This result resonates with some aspects of existent literature while not finding resonance with others. The context specific nature of this result is what makes it novel.
\end{abstract}

Keywords: Research and Development (R\&D), Technology, Small Firms, Competitive Advantage, Export Performance

\section{INTRODUCTION}

With the increased globalization of the world economy, more firms, especially smaller firms, are seeking markets abroad to sell their outputs. This is because the level of competition increases in their domestic market and, in most cases, the domestic market is too small to ensure growth and survival of the firm or the industry sector. This is true, especially for small, developing economies like those in the Caribbean where market size is very small and most economies are open to competition from firms in larger North American and European economies ${ }^{1}$. However, to operate successfully in these markets, these firms have to seek a strong source of competitive advantage (Williams, 2007; 2009; Bloodgood, Sapienza \& Almeida, 1996). Competitive advantage, however, seems to reside not only in products or services but also in intangible assets such as the firm's technological capabilities (Rodriguez \& Rodriguez, 2005). Indeed, researchers argue that among

\footnotetext{
${ }^{1}$ The English-speaking Caribbean consists of many small economies with Jamaica, with a population of 2.7million peoples being the largest individual Island. Some countries in the region have as little as 38,000 peoples. The total population of the countries in the English-speaking Caribbean and Haiti which comprise the regional integration movement called CARICOM, has less than 15 million people and a GDP of just over US\$100bill while Puerto Rico, a small economy in the wider Caribbean region has over 4 million people and a GDP of US\$93billion.
} 
the intangible resources that lead to competitive advantage for the firm, the one that is particularly significant is technological resources (Bell, Crick \& Young, 2004). With sophisticated technology, firms tend to be more innovative and can therefore gain a stronger competitive advantage through the differentiation of their products/services (Porter, 1980; Autio Sapienza, \& Almeida, 2000), which gives them superior performance in the market place. It is no doubt, therefore, that previous works have identified the possession of technology as one of the main factors that motivate firms to enter into international markets (Roper \& Love, 2002; Dhanaraj \& Beamish, 2003). However, other studies have found results that do not conform to the notion that technology has a positive impact on the export performance of the firm. Indeed, Wilmore (1992) found that Research and Development (R\&D) investment did not affect export intensity.

It is these controversial findings in the literature that have motivated this paper. The aim of the work is to test whether or not R\&D spending, a surrogate measure for the firm's technology, impacts significantly on the motivation to enter international markets through exporting. The question that will be explored in the research is: what is the relationship between technology and export performance of small firms, from small, open economies? To strengthen the work, the analysis will be grounded in the resource-based view of the firm. Most empirical studies do not have a strong theoretical lens to anchor the findings of their work; as such, it becomes difficult to replicate the findings. Grounding this work in a strong theoretical framework such as the resourcebased view of the firm will help to overcome this weakness. A further contribution of this paper is derived from the novel context in which the work was carried out. The work is done in Jamaica, which has a small, open economy. Small firms' contribution to the economy's export performance is marginal. Over 75 percent of exports are derived from minerals and petroleum re- exports, which are generally produced by large and multinational firms. Non-traditional exports which are generally produced by smaller firms account for less than 20 percent of the country's exports (STATIN, 2010). It is generally argued that if the export performance of Jamaica is to improve non-traditional exports must be targeted (Nicholls, Lyn-Cook, \& Roslow, 1989). Based on that argument, it is reasoned that by extension, more small firms will have to become involved in exporting.

Also, previous works have shown that results are not always consistent across different geographical contexts (Rodriguez \& Rodriguez, 2005); as such, there is a need for context specific work in order to guide policymakers in unique jurisdictions who are interested in promoting more small firms to enter into exporting. Further, the findings from different contexts will aid in building a better explanation on the role of technology in export performance of the firm, especially the small firm which depends heavily on technology as a source of competitive advantage.

To achieve the objectives of this paper, the remainder of the work is organized as follows. The next section will provide the theoretical background to the work. Here, there is a brief overview of the resource-based view of the firm which stresses the importance of intangible resources in driving competitive advantage in the firm. Following this the paper will then look at the variables that will be analyzed in the study. The subsequent section will look at the research methods and present the results from the analysis. The paper will end with a discussion of the results and some concluding remarks.

\section{THEORETICAL LENS - THE RESOURCE BASED VIEW OF THE FIRM}


The aim of all firms is to become profitable and maintain this profitability long-term. However, to accomplish this, the firm needs to have a competitive advantage which allows it to be superior to its competitors in the marketplace. To gain this competitive advantage the firm will have to possess a stock of resources that fulfill some critical criteria ${ }^{2}$. These criteria are valuable, scare, inimitable and non-substitutable (Barney, 1991). If resources are valuable, they may allow the firm to design strategies that improve their efficiencies. To maintain the competitive advantage, the resources must be scarce among competitors in the marketplace (Barney, 1991). Competitors should not be able to imitate the resources of a firm easily. If they can imitate resources, then the source of competitive advantage will be eroded. Inimitability then becomes an important characteristic for resources that will deliver competitive advantage (Bloodgood et al., 1996). Critically as well, if a resource is to deliver competitive advantage for a firm, it should not have substitute resources or resources that are strategically equivalent (Barney, 1991). If competitors have strategically equivalent resources, they can develop strategies similar to your firm and erode the firm's competitive advantage (Rodriguez \& Rodriguez, 2005). This interpretation seems to imply that if a firm possesses resources that meet the criteria, then the firm should be able to have superior performance over its competitors that do not possess these resources. However, the firm needs to answer an important question: which resources possess these characteristics?

The literature indicates that intangible resources are most likely to be valuable, rare, noninimitable and non-substitutable (Barney, 1991). Previous researchers have suggested that intangible resources are crucial for generating competitive advantage because, by nature, they are informative. These intangible resources are the sources from which sustainable competitive advantage can be generated (Rodriguez \& Rodriguez, 2005; Barney, 1991). Others also consider these to be the main sources of business success (Itami, 1987; Bell et al., 2004). These intangibles can be in the form of technological capital, human capital, organizational capital, and goodwill or reputational capital (Grant, 1991). However, a closer reading of the literature demonstrates that technological capital is most critical for the generation of competitive advantage because such capital is more knowledge intensive and has a tacit element that is difficult to codify in. There is also a level of specificity which increases the value proposition for the knowledge to be in the firm rather than outside it; thus, preventing it from being in other firms and reducing its transferability in the market (Rodriguez \& Rodriguez, 2005). Additionally, there is a level of complexity in technological resources that makes it difficult to identify the causes from which the resources are derived (Rodriguez \& Rodriguez, 2005). Indeed, these features of technological resources (tacit, specificity, complexity) help them to fulfill the requirements for a resource to generate sustained competitive advantage. In other words, the characteristics of knowledge resources make them valuable, scarce and non-inimitable, making it difficult for competitors to imitate.

In summary, the resource-based view suggests that for a resource to lead to a competitive advantage it must be: rare, valuable, non-inimitable and non-substitutable. Technological

\footnotetext{
${ }^{2}$ Resources according to various definitions comprise the assets, capabilities, processes, routines and knowledge possessed by the venture (Barney, 1991). In other words, resources refer to the stock of available factors owned or controlled by the venture (Amit \& Schoemaker, 1993).
} 
resources, based on their own characteristics of tacit, specificity and complexity, fulfill the criteria for generating sustained competitiveness. This competitive advantage is an important tool for firms to have in order to confront the competition and to be successful within international markets. This paper will analyze the relationship between export performance and small firms in Jamaica to determine whether or not the findings from previous works will hold in this context. The resource-based view theoretical lens has provided a good background for this analysis.

\section{THE RESEARCH LITERATURE}

\subsection{The Firm's Technology}

Technology, R\&D more specifically, is regarded as an important intangible resource that will influence the firm's decision to enter export markets (Cavusgil \& Nevin, 1981; Tybjee, 1994; Tseng, Tansuhaj \& Rose, 2004). The firm's investment in R\&D reflects a commitment to innovation. Innovation can confer competitive advantage derived from cost and differentiation to the firm. Investment in R\&D can drive the firm to produce more unique products, to customize products to fit customers' taste, and to produce higher quality products. Williams (2009) argued that higher quality product can lead to success in the export market. Case studies conducted on small Jamaican firms that export revealed that research and development does play a crucial role in improving their products for exports (Williams, 2009, p. 111). Further, researchers have argued that in a globalized market where there is an increasing demand for customized products firms with superior technology will see greater levels of competitiveness, not only in domestic markets but also in international markets (Rodriguez \& Rodriguez, 2005).

With unique offerings, firms are more likely to react positively to export stimuli because there is the perception that they can derive a competitive advantage in the export market because of their superior offering (Moen, 1999; Cavusgil \& Nevin, 1981; Burton \& Schlegelmilch, 1987; Keng \& Jiuan, 1989). Small firms, due to their limited size, cannot compete in international markets on the basis of price. They do not have sufficient resources that can provide technological economies of scales (Penrose, 1980), and will be less competitive compared to larger firms which are offering similar products at a lower price due to technological economies of scale. Having a unique product, therefore, is an opportunity for small firms to develop a niche market that will give them a competitive advantage in the international market place (Rialp, Rialp \& Knight, 2005).

While it is generally acknowledged that the investment in R \& D is good for firms, there are some inconsistencies in the results. Indeed, the relationship between the technology and export propensity has received some amount of attention in the literature (e.g. Kumar \& Siddharthan, 1994; Tseng et al., 2004; Andersson et al., 2004; Cavusgil \& Nevin, 1981; Aaby \& Slater, 1989; Miesenbock, 1988; Christensen et al. 1987; Tybjee, 1994; Dhanaraj \& Beamish, 2003) but with mixed results. While some researchers have found a positive relationship between technology and export propensity, (e.g. Tseng et al., 2004, Andersson, Gabrielsson \& Wictor, 2004), others found no statistically significant relationship (e.g. Tybjee, 1994; Rodriguez \& Rodriguez, 2005 etc.). However, where export intensity is concerned, it is not quite clear as to the impact of technology. For example, Reid (1986) found that technology will encourage the firm into early exporting, but in terms of its impact on future success (e.g. increased export revenue) there was 
no strong relationship discovered. Tybjee (1994) found that R\&D has a positive influence on export intensity. This was reflected in results which show that firms in industries with high R\&D spending reported a higher proportion of their sales from international markets. In a similar vein, Rodriguez \& Rodriguez (2005) found R\&D spending to be significant with regard to export intensity.

The performance and strategies of a firm depend heavily on the industry structure within which it operates (Barney, 1991). Firms in industries that are technology driven are more likely to innovate and export (Tybjee, 1994). This is possible due to the competitive advantage to be gained from developing unique and customized products with the new technology. A large number of empirical studies show that firms in high technology industries are more likely to be exporters (e.g. Bell et al., 2004; Crick \& Jones, 2004; Tybjee, 1994, etc.).

From a close reading of the literature, an important issue that seems to emerge regarding investment in R\&D is that it does not automatically translate into increased capacity and competitive advantage that can help firms to become successful in foreign markets (Williams, 2009; Bloodgood et al., 1996). The investment may not result in product innovations or process innovations that could give the firm a competitive advantage. The competitive advantage from this investment will be derived from what is achieved (e.g., reduction in production costs). The point is that merely investing in $\mathrm{R} \& \mathrm{D}$ will not always provide technological economies of scale, which is an important driver of competitiveness for success in international markets. Indeed, the rapid revolution in technology has narrowed the technological gap which once existed between small and large firms. With the life cycle of technology becoming much shorter today than say three decades ago, more firms are obliged to enter the international market place in order to recover R\&D costs which cannot be recovered in their domestic market (Tybjee, 1994). This form of technology driven export supports the thesis of Vernon's (1966) product life cycle theory. Indeed, this may help to explain the results that show a positive relationship between exports and technology. If one should follow the logic of the resource-based theory, a higher stock of technological resource will lead to greater competitive advantage (Barney, 1991), which will give the firm greater incentive to enter foreign markets. It is this logic that has guided our theoretical expectation regarding the relationship between technology and the firm's export propensity.

\subsection{Social Capital of the Owner}

The most important point from the stage theory of internationalization is that the more international experience a firm possesses the better able it is to expand abroad (Johanson \& Vahlne, 1977). Certainly, from the resource-based theory of venture internationalization, international experience is seen as a valuable asset from which the firm can gain a competitive advantage, better enabling it to enter foreign markets. Bloodgood et al., (1996) argued that some of the international experience in the firm is located within individuals who form these firms (entrepreneurs), thus they may capitalize on this experience and expand internationally. In other words, this international experience is derived from the owner's social capital.

Having lived, worked or studied abroad is an important source of social capital for entrepreneurs. This social capital gives them a better knowledge of foreign cultures, business practices, and laws and regulations in foreign markets. This knowledge will better prepare them to take on 
business in foreign markets, which are more complex and different from the domestic market. It will also help to reduce the psychic distance ${ }^{3}$ to these markets. If stage theory has any validity, it is expected that with reduced psychic distance more firms with entrepreneurs who have a high level of social capital will enter export markets.

Social capital can also be used as a synonym for network building, another valuable resource that can provide the firm with a competitive advantage that is crucial for foreign market entry. An area of social capital that is crucial for networking is foreign travel. Foreign travel will allow entrepreneurs to meet prospective customers, identify business opportunities and generate foreign sales for the firm's products. This international exposure will broaden the owners' networks compared to limited domestic networks. The foreign travel experience of the owner of small firms has received extensive empirical attention in the literature with the results being consistent in one direction, that is, a positive relationship with export propensity (e.g., Williams \& Chaston, 2004; Keng \& Jiaun, 1989; Dichtl et al., 1990; Obben \& Magagula, 2003). If we assume that social capital is a valuable resource for the firm, then the resource-based theory will suggest that there is, indeed, a positive relationship between the social capital of the entrepreneur and the firm's export propensity.

\subsection{Firm Size}

From the perspective of the resource-based theory, it appears that the size of the firm does matter when making the decision to enter into export markets. Larger firms, due to their higher number of employees, will have access to more resources (e.g. experienced managers, financial resources, etc.) that small firms do not have. Because exporting demands a large amount of resources, small firms that do not have access to these critical resources will be constrained in their ability to enter international markets. Indeed, researchers have used firm size as a surrogate measure of the firm's resource stock (Bonaccorsi, 1992). Large firms are said to have more resources (e.g., financial, technology, human capital) than smaller firms. The access to more resources enables large firms to successfully enter and operate in export markets (Aaby \& Slater, 1989; Katsikeas \& Piercy, 1993; Philp, 1998). The empirical evidence, however, does not support this one-dimensional view. For all the attention given to firm size as an explanation for exporting, there seems to be very little agreement regarding its impact on either export propensity or export success (Aaby \& Slater, 1989).

Size, as an explanatory variable, has received much attention in the literature on the firm's export behavior (e.g., Calof, 1993; 1994, Daniels \& Guyboro, 1976; Andersson et al., 2004; Mittelstaedt, Harben \& Ward, 2003; Hall \& Tú, 2004; Yaprak, 1985; Keng \& Jiuan, 1989; Pope, 2002; Bilkey \& Tesar, 1977; Leonidou \& Katsikeas, 1996; Miesenbock, 1988; Burton \& Schlegelmilch,1987; Reid, 1981; Czinkota \& Johnson, 1983; Cavusgil \& Nevin, 1981; Whitey, 1980; Bonaccorsi, 1992; Cavusgil,1984a, 1984b; Dichtl et al,1990). The most common finding is the positive relationship between firm size and export propensity Miesenbock, 1988). When using size as a surrogate for the firm's resources, studies have suggested that there is a critical minimum size in order for exporting to take place (Mittelstaedt et al., 2003).

3 This is a term that is used to capture differences between home and host markets. See for example, Johanson \& Vahlne, 1977, \& Ogrady \& Lane, 1997 for a definition of the concept. 
Their recommendation is that below 20 employees exporting becomes infeasible. This argument finds support with that of Bilkey (1978) who discovered that beyond a certain point exporting is positively correlated with firm size, but below a minimum point, no correlation exists. Because size reflects the productive capacity of the firm, below a critical minimum the firm will not have sufficient capacity to initiate exporting (Mittelstaedt et al., 2003). Mittelstaedt's argument, however, is weakened when using number of employees to measure size. Firms with less than five employees are observed operating in the export market (e.g. Bilkey \& Tesar, 1977; Philp, 1998; Calof, 1993; Moen \& Servias, 2002); whereas, the proxy for sufficient productive capacity suggests 20 employees, minimum. Size as a surrogate for productive capacity seems to be an argument which better suits continued export development than export propensity.

Although there seems to be a heavy bias towards a positive relationship between firm size and export performance, there are still inconsistencies in the results. Hall \& Tú (2004), analyzed the impact of size on both measures of export performance; that is, export propensity and export intensity and found different results ${ }^{4}$. As it relates to export intensity, they found a negative relationship with size, while for export propensity there was a positive relationship with size. Other researchers found no relationship with size and export intensity (e.g. Czinkota \& Johnson, 1983; Cavusgil, 1984b). Czinkota \& Johnson, (1983) concluded that size did not substantially differentiate between managers' attitudes and the firm's experiences in exporting. From a more critical look at the size and export propensity debate, Hall \& Tú (2004) argued that it is the fixed cost associated with entry which makes size an important variable in the decision to export. The high fixed cost involved with exporting is important because small firms that are resource poor are more vulnerable to sinking costs. To elucidate, fixed cost associated with search for market, negotiation, certification such as ISO and HACCP can be exorbitant. Small firms that are low on resources will not be able to afford these costs; these costs may dissuade firms from considering exporting.

While the fixed cost argument espoused by Hall \& Tú (2004) is compelling in justifying size as a significant variable that impacts export performance, if the firm has a highly competitive product and there is a growing demand in the export market for this product, there are methods which can be used to overcome the limitation of fixed cost. For example, firms may get assistance for certification from domestic governments. Some small firms may also network with larger firms which are resource rich and have already borne the fixed cost involved in exporting (Coviello \& McAulley, 1999; Beamish, 1987; Bonacorssi, 1992; Lipparini \& Lorenzo, 1999). Networking will help smaller firms to get their products in the export market at a lower cost than if they were to seek the market on their own.

\subsection{Firm Age}

If we accept the premise that as firms grow older they will acquire more resources (Autio, 2005), then the resource-based view prediction that older firms will have considerably more resources

\footnotetext{
${ }^{4}$ Export propensity looks at whether or not a firm export, while export intensity looks at the portion of sales from export as a percentage of total sales
} 
than younger firms is a plausible premise from which to analyze how the role of the firm's age will impact its ability to export. Because older firms tend generally to have a larger stock of resources than younger firms, the resource-based view of venture internationalization, drawing on the theoretical lens of the resource-based theory, argues that they will be better able to build an international basis (Bloodgood et al., 1996). Process theory of internationalization posits that firms progress in a stepwise manner in moving from the domestic market to international markets (Johanson \& Wiedersheim-Paul, 1975; Johanson \& Vahlne, 1977, 1990; Czinkota, 1982; Cavusgil 1980). Underlying this gradual process is the assumption that firms will need to develop their knowledge of the foreign market before making a commitment to allocate huge amounts of resources to that activity. In other words, managerial learning, which is a reflection of age, becomes a critical resource for firms who intend to export.

Indeed, Jovanovic (1982) sees firm age as a reflection of learning. Learning, according to the postulates of the process theory, is a critical resource that will enable firms to enter export markets. International markets are very diverse and business practices are different from those in the home market. To operate effectively in these markets, theorists of the incremental stage orientation argue that firms will have to develop skills relating to the foreign market (e.g. language), learn the culture of these markets, and develop confidence in overseas operation before large volumes of resources are. Gathering this knowledge and experience comes overtime. As soon as the firm grows older, it will gather a higher stock of knowledge on how overseas markets operate. The knowledge which firms acquire over time will help them to overcome the "liability of foreignness" (Hymer, 1976), and "liability of newness" (Stinchcombe, 1965), factors that prevent younger firms from surviving in the international market (Welch \& WeidersheimPaul, 1980; Rhee, 2002).

The gradualist view has come under heavy scrutiny given the rise of born global and international new ventures firms (Knight \& Cavusgil, 2004; Oviatt \& McDougall, 1994). Firms from both the high technology and manufacturing sectors are observed going international even before they start any form of operation in the domestic market (Crick, 2004). This evidence further bemused the proponents of stage theory who argue that age is a reflection of experience, know-how, and alleviates the liability of foreignness and newness. Researchers recognize that younger firms are internationalizing at an even faster rate than older ones (Knight \& Cavusgil, 2004). This fact underscores the numerous critiques that have been leveled at the stage school of thought (Johanson \& Vahlne, 1990).

Although there are sound theoretical arguments which suggest that firms may not necessarily enter export markets incrementally (e.g. Moen \& Servias, 2002), the contention in the empirical literature as to the impact of the firm's age on export performance (propensity, intensity) continues. A recent Swedish study by Andersson et al., (2004) showed that the firm's age is not a significant factor in determining the level of internationalization. Keng \& Jiuan (1989) found that there is no statistically significant difference between younger and older firms' interests in exporting. They concluded that this finding does not give support to the contention that younger firms are more interested in exporting than older ones.

However, the literature on organization theory provides arguments to suggest that younger firms are more interested in exporting than older ones (Rhee, 2002; Autio et al., 2000). This school of 
thought points to structural inertia as a result of age. It posits that structural inertia in a firm increases with the age of the firm. Therefore, results show the slower response rate of change in older firms than younger firms. Since exporting calls for important changes to be made in a firm's operational activities, it is expected that older firms will respond less quickly than younger firms.

While this theoretical lens may have some merit, the literature still has inconsistent findings as it relates to this variable. In a Peruvian study, Daniels and Goyburo (1976) found evidence that older firms are more likely to become exporters. Peruvian firms serve their local market first then gradually move to the export market. However, this finding was before the rapid liberalization of trading systems around the world and also the massive improvements of information and communication technologies. As a result, it could reasonably be expected that firms operating in this era will behave gradually towards exporting. Today, trade liberalization, improvements in information and communication technologies have provided a strong stimulus inducing firms to enter export markets. Therefore, it may be argued that age will no longer be a barrier to exporting. More recently Brouthers and Nakos (2005) showed that older firms are more likely to be more successful in the export market without measuring export performance as export propensity. The interpretation is that these firms are more likely to become exporters. Moreover, because of the belief that firms gather resources over time and export initiation requires large amount of resources, we anticipate older firms to have more resources to build an international basis to have a greater propensity of exporting than younger ones.

Overall, the resource-based view of the firm suggests that resources are critical for building an international base and for being successful in the export market. It appears that the higher the resource stock the greater the likelihood of the firm being successful in the export market. Viewing $\mathrm{R} \& \mathrm{D}$ through the lens of resources provides a strong basis for analyzing R\&D impacts export performance.

The method employed for helping to shed light on this issue is discussed in the next section.

\section{METHODOLOGY}

The data employed in this empirical research were derived from an interviewer administered survey (Babbie, 2004) of 92 firms in the manufacturing and agricultural sectors in the Jamaican economy. Jamaica provides a novel context for this research to take place; the economy is small with a GDP of approximately $\$ 13$ billion and a population of 2.7 million. Given this small market size, exporting becomes an important activity for the growth of firms and industry sectors. Further, Jamaica is in very close proximity to the United States, the world' largest economy with GDP of over $\$ 13$ trillion and a population of over 300 million people. This distance provides an opportunity for Jamaican firms to export their outputs to the US market with minimum transportation costs. Despite the opportunities geographic location provides, the general macro-economic indicators in Jamaica are very weak with macro-economic instability as a regular feature of the Jamaican economy for over 30 years. Exporting is seen as one of the most feasible ways to expand this economy and reverse the negative trends of its macro- economic performance. As a small economy, producing for the internal market will not be sufficient to derive economies of scale in production and to expand the firm. Indeed, export policy 
makers are interested in persuading more firms to export as a way to improve the growth performance of the Jamaican economy. To do this, they will have to be clear on the factors that motivate firms to export, especially the small firms. This paper will focus on technology, one of the most critical factors, in order to determine its impact on the firm's export performance.

\subsection{Data Collection Strategy}

The survey data for this study were derived from face-to-face interviews with small firms that are locally-owned in the Jamaican economy ${ }^{5}$. The interviewer administered survey was deemed necessary in order to prevent the number of "don't know" responses to the questions on the questionnaire. Also, given that generally the education level of the owners of small firms is not very high compared to the rest of the population, it was necessary to ensure that all the questions were clearly understood. The interviewer in this case was able to explain the ambiguities on the survey instrument.

The interviews were conducted using a structured instrument administered by the interviewer. The instrument consisted of questions on the export performance of the firm, the motivation for exporting, and reasons for not exporting. Respondents were asked the percentage of their revenue they spend to conduct R\&D, the reasons for entering into exporting, the number of employees in the firm, and the position of the owner before starting the business. The questions on the instrument were derived from previous works on the subject. The original instrument with questions from previous works on the subject was piloted tested in the study context before the main study. From the pilot, a number of questions were dropped given their irrelevance to the subject and the inability to obtain responses. For face validity, the instrument was circulated to academics working in the area to gain their feedback. The final instrument reflects questions that were vetted through a pilot study and peer- reviewed from academics within the area.

The respondents were asked to reflect on the questions asked by the interviewer and to respond as best as possible. Where there was need for clarification, the interviewer would explain ambiguous items to the interviewees. Interviews lasted for about 60 minutes on average as the interviewer and the key informant discussed some issues relating to financial information of the firm. When the respondent gave a response, the interviewer would record the answer on the questionnaire. At the end of the interview, the interviewer would repeat the answers to the interviewee in order to ensure that the correct items were ticked on the instrument. In some cases, respondents were willing to elaborate on some points such as their export experience. Their answers were recorded with a tape recorder. These anecdotes were not used for this paper.

Firms in specific sub-sectors of the manufacturing sector (food, beverages and tobacco, garment and textile, furniture and fixtures, chemical and rubber, etc.) and the agricultural sector (coffee, tea, vegetables, fish, fruits, etc.) were interviewed to gather data from the survey for this study. The key informants in all cases were the owner of these firms. For firms to be selected in this study, they had to meet the criteria of having 100 or less employees (the definition used to operationalize small firms in this study) and must be locally-owned. Meeting the criteria is

\footnotetext{
${ }^{5}$ Small firms are defined in this study as those with 100 or less employees. This is consistent with the definitions used by other studies that look at small firms that are engaged in exporting (Williams, 2009; Bell et al., 2004).
} 
important in order to reduce any biases in their export activities. Firms that are subsidiaries of larger and multinational organizations can easily sell their products to their parent company. Although this constitutes exports, it does not take into consideration the pro-activeness of the action, which is critical for a study of this nature. Since the sample frame was small, all firms were contacted for participation in the study. The final list of firms was narrowed down to those who consented to participate in the study.

\subsection{The Research Variables}

For the study, variables were classified as dependent and independent in order to shed light on the research issue. The dependent variable is export performance as measured by export propensity. This captures whether or not the firm exports its products. The variable is operationalized using a binary variable where 1 is given to the firm that exports and 0 to firms who don't export. There were multiple independent variables for this study. Technology, where R\&D investment is used as a surrogate measure, was operationalized by the portion of the firm's revenue (as measured in percentage) that is invested in R\&D. Social capital is also another independent variable. It is measured by the entrepreneur's travel experience abroad. Other independent variables include firm size as measured by the number of employees and firm age as measured by the number of years elapsed since the firm started operations. Table 1 below presents a summary of these variables and how they are operationalized.

Table 1: Operationalization of Research Variables

\begin{tabular}{|c|c|c|}
\hline VARIABLE NAME & $\begin{array}{l}\text { OPERATIONAL } \\
\text { MEASURE }\end{array}$ & PREVIOUS WORKS \\
\hline FIRM'S TECHNOLOGY & $\begin{array}{c}\text { THE FIRM'S SPENDING ON } \\
\text { R\&D AS A PORTION OF SALES }\end{array}$ & $\begin{array}{c}\text { MOEN, 1999; TYBJEE, 1994; } \\
\text { RODRIGUEZ \& RODRIGUEZ, } \\
2005\end{array}$ \\
\hline SOCIAL CAPITAL OF OWNER & $\begin{array}{c}\text { DUMMY VARIABLE } \\
\text { 1= WORKED OR LIVED } \\
\text { ABROAD FOR }>1 \text { YEAR } \\
0=\text { OTHERWISE }\end{array}$ & $\begin{array}{c}\text { AABY \& SLATER, 1989; } \\
\text { WILLIAMS \& CHASTON, } 2004\end{array}$ \\
\hline FIRM SIZE & NUMBER OF EMPLOYEES & $\begin{array}{c}\text { POPE, 2002; MEHRAN \& MOINI, } \\
\text { 1999; OBBEN \& MAGAGULA, } \\
2003\end{array}$ \\
\hline FIRM AGE & $\begin{array}{c}\text { NUMBER OF YEARS SINCE } \\
\text { FIRM WAS LEGALLY } \\
\text { ESTABLISHED }\end{array}$ & $\begin{array}{c}\text { DAS, 1994; BROUTHERS \& } \\
\text { NAKOS, } \\
2005\end{array}$ \\
\hline EXPORT PERFORMANCE & $\begin{array}{c}\text { DUM MY VAR IAB LE } \\
1=\text { EXP ORT ER } \\
0=\text { NON- EXPORTER }\end{array}$ & $\begin{array}{c}\text { OBBEN \& MAGAGULA, 2003; } \\
\text { RODRIGUEZ \& RODRIGUEZ, } \\
2005\end{array}$ \\
\hline
\end{tabular}

Further, Table 2 below presents a sample profile of the firms that were interviewed for the study. 
Table 2: Descriptive Statics of Sample Firms

\begin{tabular}{|c|c|c|c|c|}
\hline & $\begin{array}{c}\text { EXPORTER } \\
\mathrm{N}\end{array}$ & $\%$ & \begin{tabular}{|c|} 
NON- \\
EXPORTER \\
N
\end{tabular} & $\%$ \\
\hline \multicolumn{5}{|l|}{ NUMBER OF EMPLOYEES } \\
\hline$<10$ & 11 & 25 & 26 & 54.2 \\
\hline $10-19$ & 7 & 15.9 & 9 & 18.8 \\
\hline $20-29$ & 7 & 15.9 & 2 & 4.2 \\
\hline $30-39$ & 2 & 4.5 & 1 & 2.1 \\
\hline $40-49$ & 3 & 6.8 & 6 & 12.25 \\
\hline $50-100$ & 14 & 31.8 & 4 & 8.3 \\
\hline TOTAL & 44 & 100 & 48 & 100 \\
\hline \multicolumn{5}{|l|}{$\begin{array}{c}\text { EDUCATION LEVEL OF } \\
\text { MANAGER }\end{array}$} \\
\hline PRIMARY & - & & 1 & 2.1 \\
\hline SECONDARY & 11 & 25 & 17 & 35.4 \\
\hline UNIVERSITY & 29 & 65.9 & 17 & 35.4 \\
\hline OTHER & 4 & 9.1 & 13 & 27.1 \\
\hline TOTAL & 44 & 100 & 48 & 100 \\
\hline \multicolumn{5}{|l|}{ YEAR OF ESTABLISHMENT } \\
\hline BEFORE 1970 & 8 & 18.2 & 5 & 10.4 \\
\hline $1970-1975$ & 6 & 13.6 & 5 & 10.4 \\
\hline $1976-1981$ & 6 & 13.6 & 13 & 27.1 \\
\hline 1982- 1987 & 4 & 9.1 & 8 & 16.7 \\
\hline $1988-1993$ & 7 & 15.9 & 2 & 4.2 \\
\hline 1994-1999 & 8 & 18.2 & 10 & 20.8 \\
\hline $2000-2004$ & 5 & 11.4 & 5 & 10.4 \\
\hline TOTAL & 44 & 100 & 48 & 100 \\
\hline
\end{tabular}




\subsection{Data analysis}

The dependent variable is dichotomous in nature; as such, a model from the qualitative genre of econometric models was utilized in order to determine how the independent variables relate to the dependent variable. The logit model was the tool used to carry out the analysis. It helped us to predict the likelihood of a firm becoming an exporter given its investment in technology, the social capital of the owner, and the age and size of the firms. Furthermore, because the sample frame for small, locally owned firms in Jamaica is not known, it is difficult to estimate the true population of mean and variance. As such, one cannot be sure about the normality of the population from which the sample was drawn. The logit model was employed to analyze data from this population to help overcome the problems identified. The logit model is less sensitive to violation of the normality assumption (Gujarati, 2003). The form the logit model takes for this analysis is presented below.

$\operatorname{Logit}(\mathrm{Y})=\ln (\mathrm{P} / 1-\mathrm{P})=$

Where:

the firms' technology social capital as measured by foreign travel firm size firm age.

The dependent variable Y captures the firm's export performance; if it is an exporter, it gets a 1 and if not, a 0 .

Below, the paper outlines the results derived from the analysis of the data.

\section{RESULTS}

Table 3 shows the findings from the model which predicts which variable is most likely to influence the decision to become an exporter.

The results in Table 3 suggest that firm size, not technological capabilities, is the most significant variable in determining whether or not small, locally-owned Jamaican firms export their goods and services abroad. This result, like previous works, seems to be consistent with some of the literature (e.g., Tybjee, 1994; Rodriguez \& Rodriguez, 2005) but is inconsistent with findings from other areas of the work. The interpretation here is that firm size, is the most significant variable when making a decision to enter into export markets. According to the results, as firms grow larger in size they become more likely to become exporters.

Table 3: Logistic Regression-Unrestricted Model (N=92)

\begin{tabular}{|c|c|c|c|c|}
\hline $\begin{array}{c}\text { INDEPENDENT } \\
\text { VARIABLES }\end{array}$ & & WALD & SIG. & EXP0 \\
\hline CONSTANT & -1.065 & 2.895 & 0.089 & 0.345 \\
\hline $\begin{array}{c}\text { FIRM'S } \\
\text { TECHNOLOGY }\end{array}$ & 0.205 & 0.158 & 0.691 & 1.228 \\
\hline $\begin{array}{c}\text { SOCIAL } \\
\text { CAPITAL }\end{array}$ & 0.955 & 2.469 & 0.116 & 2.597 \\
\hline
\end{tabular}




\begin{tabular}{|c|c|c|c|c|}
\hline FIRM SIZE & 0.025 & 4.647 & $0.031^{*}$ & 1.025 \\
\hline FIRM AGE & 0.038 & 0.100 & 0.751 & 1.039 \\
\hline $\begin{array}{c}\text {-2LL (INITIAL } \\
\text { MODEL) }\end{array}$ & 127.4 & & & \\
\hline $\begin{array}{c}\text {-2LL (FINAL } \\
\text { MODEL) }\end{array}$ & 115.2 & & & \\
\hline $\begin{array}{c}\text { 2 (DF) } \\
\text { (FINAL MODEL) }\end{array}$ & $12.2^{* *}$ & & & \\
\hline $\begin{array}{c}\text { 2 (DF) } \\
\text { HOSMER \& } \\
\text { LEMESHOW } \\
\text { TEST }\end{array}$ & $12.77 * * *$ & & & \\
\hline $\begin{array}{c}\text { NAGELKERKE } \\
\text { R }\end{array}$ & 0.17 & & & \\
\hline R2L & 0.09 & & & \\
\hline $\begin{array}{c}\text { \% CORRECT } \\
\text { PREDICTION }\end{array}$ & 64.1 & & & \\
\hline
\end{tabular}

Dependent variable is export performance, that is whether or not the firm exports.

* Variables are significant at the 0.05 level of significance

** Statistic is significant at the 0.05 level of significance $\quad(p=0.02)$

$* * *$ Test is non-significant at the 0.05 level of significance $\quad(\mathrm{p}=.12)$

$\mathrm{R}_{\mathrm{L}}^{2}=1$-(Final model -2LL/ Initial model -2LL

While the result seems strong, further tests were carried out to detect whether or not the model was influenced by the inclusion of specific variables. The model was evaluated using firm size and the social capital. Social capital was chosen because it is significant at the 10 percent level of significance. This is referred to as the restricted model. The results from this analysis are reported in Table 4.

Indeed, the results show that the outcome from the analysis is not influenced by the choice of variables in the model. From the restricted model, the results revealed that it is firm size that determines export performance, a similar finding to the unrestricted model. These results seem to be robust. The model diagnostics also indicate that the model fits well with the data. The Hosmer \& Lemeshow test, which looks at the difference between the predictive and the actual model, was not significant in any of the analyses. This non-significant result suggests that the predictive and the fitted model are not very different. In both sets of models, the R2 measures, which are goodness of fit measures, also remained stable after the sensitivity analysis. These are other indicators of 
stability of the results.

Table 4: Restricted Model

\begin{tabular}{|c|c|c|c|c|}
\hline $\begin{array}{c}\text { INDEPENDENT } \\
\text { VARIABLES }\end{array}$ & & WALD & SIG. & EXP0 \\
\hline CONSTANT & -0.867 & 6.849 & 0.009 & 0.420 \\
\hline $\begin{array}{l}\text { SOCIAL } \\
\text { CAPITAL }\end{array}$ & 0.983 & 2.651 & 0.103 & 2.674 \\
\hline FIRM SIZE & 0.025 & 5.749 & $0.017^{*}$ & 1.025 \\
\hline $\begin{array}{l}\text {-2LL (INITIAL } \\
\text { MODEL) }\end{array}$ & 127.4 & & & \\
\hline $\begin{array}{l}\text {-2LL (FINAL } \\
\text { MODEL) }\end{array}$ & 115.2 & & & \\
\hline $\begin{array}{c}2 \text { (DF) } \\
\text { (FINAL } \\
\text { MODEL) }\end{array}$ & $11.9 * *$ & & & \\
\hline $\begin{array}{c}{ }^{2}(\mathrm{DF}) \\
\text { HOSMER \& } \\
\text { LEMESHOW } \\
\text { TEST }\end{array}$ & $4.6^{* * *}$ & & & \\
\hline $\begin{array}{c}\text { NAGELKERKE } \\
R^{2}\end{array}$ & 0.16 & & & \\
\hline $\mathbf{R}^{2} \mathbf{L}$ & 0.09 & & & \\
\hline $\begin{array}{l}\text { \%CORRECT } \\
\text { PREDICTION }\end{array}$ & 64.1 & & & \\
\hline
\end{tabular}

Dependent variable is export performance, that is whether or not the firm exports.

* Variables are significant at the 0.05 level of significance

** Statistic is significant at the 0.05 level of significance $\quad(p=0.00)$

$* * *$ Test is non-significant at the 0.05 level of significance $(\mathrm{p}=0.80)$

$\mathrm{R}^{2}{ }_{\mathrm{L}}=1$ - (Final model -2LL/ Initial model -2LL)

In order to ensure that the model is not affected by multi-collinearity, the variance inflation factor (VIF) for the independent variables was calculated. The results revealed that there is no multicollinearity in the model as the VIF values were below 10. Table 5 below displays these results. 


\section{Table 5: Test for Multi-Collinearity}

\begin{tabular}{c|ccc}
\hline \multicolumn{1}{|c}{ Factors } & Tolerance & VIF \\
\hline 1 & Social Capital & 0.905 & 1.105 \\
\hline 2 & Firm Size & 0.757 & 1.322 \\
\cline { 1 - 1 } 3 & Firm Age & 0.914 & 1.094 \\
\hline 4 & Firm's Technology & 0.863 & 1.159 \\
\hline
\end{tabular}

The results from this analysis have supported some of the findings in the existent literature while not finding resonance with others. The significance of this for the extant context is very important.

\section{DISCUSSION}

This study aimed to understand how technological capabilities impact the decision of small, locally-owned firms from a low growth economy to export their outputs abroad. From a resourcebased view of the firm lens, technological resources are seen as critical for the firm as they provide a competitive advantage to the firm which will help it to gain superior performance in the market place. Technology allows the firm not only to reduce its cost but to differentiate its products so that it can gain an advantage over its competitors. Differentiation and cost advantages allow the firm to have a greater competitive capacity on the international market. Therefore, it is expected that any analysis of technological capabilities and firm performance should produce a positive result for this relationship. However, the research presented in this paper, like others in the extant literature (e.g., Tybjee, 1994; Rodriguez \& Rodriguez, 2005; Dhanaraj \& Beamish, 2003), found that there was no significant relationship between technology and the firm's export performance in the firms studied.

This result can be understood in the context of the environment in which the firms operate. The literature reports on a number of works (e.g. Basile, 2001; Roper \& Love, 2002), which show that technology has a positive relationship with export performance but, more specifically, technology affects export performance based on the sector in which the firm is operating. Rodriguez \& Rodriguez (2005) found that there were sectorial differences when observing export performance of firms in Spanish-speaking countries. Industries that are heavily technologically dependent will see technology as crucial for their export business because it is their main source of competitive advantage in the market place. Industries that are less technological intensive will see the technological capabilities of the firm as the most important factor to determine their export performance.

The firms studied in this paper are firms from industry sectors that are not technological intensive in their outlook. The firms are from the manufacturing sector with sub-sectors such as textile, food, drinks, tobacco, etc., and agriculture with sub-sectors such as tea, coffee, fish, etc. These subsectors could hardly be considered technological intensive. Indeed, Rodriguez \& Rodriguez (2005) also reported that in sub-sectors such as tobacco, food, drinks, wood, etc. technological capability of the firm was not a significant variable in determining export performance. This result fits very well 
in the Jamaican context. It appears that technology did not turn out to be a significant variable because of the sectors in which the firms operate. However, although the firm's technological capability is not seen as statistically significant to its export performance, it should not be interpreted that technology is not an important resource in the firm. Technology is one of the most critical resources to generate competitive advantage for firms, especially small, resource poor firms. The impact however, may be difficult to capture due to the limited way in which this paper measured the concept. It merely looked at investment in R\&D as a proxy for technological capabilities. Other measures such as the innovation that comes from the investment in the R\&D could possibly provide greater insight as to how technology impacts export performance.

\section{IMPLICATIONS OF THE FINDINGS}

The findings from this work suggest that small, locally-owned firms will have to expand their firms if they are to export their outputs abroad. Remaining small firms will not guarantee success in the export business on the international market. Size and resources are positively related and, as such, the larger the firm the more resources it will have to invest in exporting. Managers in small firms will therefore have to invest in strategies that will lead to the growth of their firms if they want to be successful in the export market. It is also important that they do not ignore the use of technology even though this research did not find it to be critical for export performance. Technology is resourceful for competitive advantage of smaller firms. Firms should invest in technology that will generate innovation, which in turn will provide the competitive advantage for superior performance in the international marketplace.

The study has implications for future researchers as well. Other research should look at the level of innovation in the firms studied as a way to better understand the impact of technology on export performance. This research merely looked at R\&D spending which is not sufficient to capture innovation in the firm. Measures of innovation such as patents derived, new products, etc. can be used as proxies for technological capabilities that impact export performance in the firm. Further, since the issue of impact of technology on export performance is not unique to any geographical location, it will be good for other researchers to carry out a similar study to this one in other economies with similar characteristics to those of Jamaica such as other Caribbean countries like Trinidad and Tobago, Barbados, and Guyana. This will help to determine the external validity of the work. It will also provide more empirical evidence on the subject so that theorist can build a general theory on the firm especially as it relates to the role of technology on export behavior of the smaller firm.

Additionally, the research focused upon export propensity as a measure of export performance; it is not always clear from this measure how technology is utilized in order to enhance export performance. Consequentially, the study may not accurately capture the true impact of R\&D on export performance. Other measures of performance could be utilized to determine if the firm is a high exporter or a low exporter. One could then compare technology use among high exporters and low exporters. This will require future researchers to collect information on the export intensity of firms in order to help categorize firms export performance according to these variables. 


\section{CONCLUSIONS}

The research of this study showed that firm size determines export performances of small, locallyowned firms. This finding is interesting given the novelty of the context from which it is derived. The finding also supports one strand of the literature that claims there was no relationship between export performance and technological capabilities. At the same time, the finding is inconsistent with another strand of the literature which found that there is a positive relationship between export performance and technological capabilities of the firm.

This paper concludes that the industry sector in which the firm operates appears to be the main determinant of whether or not technological capabilities have a statistically significant impact on export performance. Industry sectors that are less technological intensive do not view technology as the most important factor in determining whether or not firms export. The sectors studied in this paper are clearly not technologically intensive and, as such, the results can be understood in that context. The main lesson is that the importance of technology in the export process acts as a function of the industry sector. As such, results in the literature cannot be generalized; instead context specific studies are needed to determine the role of technology in the export processes of small firms.

\section{REFERENCES}

Aaby, N. E. \& Slater, S. F. (1989). Management influences on export performance: A review of the empirical literature 1978-88. International Marketing Review, 6(4), 7-26.

Andersson, S., Gabrielsson, J. \& Wictor, I. (2004). International activities in small firms: Examining the factors influencing the internalization and export growth of small firms. Canadian Journal of Administrative Sciences, 21, 22-34.

Autio E, Sapienza, H. J., Almeida, J. G. (2000). Effects of age at entry, knowledge intensity, and imitability on international growth. Academy of Management Journal, 43(5), 909-924.

Barney, J. B. (1991). Firm resources and sustained competitive advantage. Journal of Management, 17, 99-120.

Basile, R. (2001). Export behavior of Italian manufacturing firms over the nineties: The role of innovation. Research Policy, 30, 1185 - 1201.

Beamish, P. W. (1987). Joint ventures in LDCs: Partner selection and performance. Management International Review, 27(1), 23-37.

Bell, J., Crick, D. \& Young, S. (2004). Small firm internationalisation and business strategy: An exploratory study of "knowledge intensive" and "traditional" manufacturing firms in the UK. International Small Business Journal, 22(1), 23-56.

Bilkey, W. J. (1978). An attempted integration of the literature on the export behavior of firms.

Journal of International Business Studies, Spring/ Summer, 33-46.

Bilkey, W. J., \& Tesar, G. (1977). The export behaviour of smaller-sized Wisconsin manufacturing firms. Journal of International Business Studies, Spring/Summer, 93-98.

Bloodgood, J. M., Sapienza, H. J. \& Almeida, G. J. (1996). The internationalization of new high potential U.S. ventures: Antecedents and outcomes. Entrepreneurship: Theory and Practice, 20 (4), 61-76.

Bonaccorsi, A. (1992). On the relationship between firm size and export intensity. Journal of International Business Studies. 23 (4), 605-635.

Brouthers, L. E. \& Nakos, G. (2005). The role of systematic international market selection on small 
firms' export performance. Journal of Small Business Management, 43(4), 363- 381.

Burton, F. N. \& Schlegelmilch, B. B. (1987). Profile analyses of non-exporters versus exporters grouped by export involvement. Management International Review, 27(1), 38-49.

Calof, J. L. (1993). The impact of size on internationalization. Journal of Small Business Management 31(4), 60-69.

Calof, J. L. (1994). The relationship between firms size and export behavior revisited. Journal of International Business Studies, Second Term, 367-387.

Cavusgil, S. T. (1980). On the internationalization process of firms. European Research, 8 (November), 273-281.

Cavusgil, S. T. (1984a). Organizational characteristics associated with export activity. Journal of Management Studies, 21(1), 3-22.

Cavusgil, S. T. (1984b). Differences among exporting firm based on their degree of internationalization. Journal of Business Research, 12, 195-208.

Cavusgil, S. T. \& Nevin, J. R. (1981). Internal determinants of export marketing behavior: An empirical investigation. Journal of Marketing Research, 18, 114-119.

Christensen, C. H., da Rocha, A. \& Gertner, R.K. (1987). An empirical investigation of the factors influencing exporting success of Brazilian firms. Journal of International Business Studies, 18, 61-77.

Coviello, N. E. \& McAuley, A. (1999). Internationalization and the small firm: A review of contemporary empirical research. Management International Review, 39(3), 223-237.

Czinkota, M. R. (1982). Export Development Strategies. New York: Praeger Publishers. Czinkota, M. R. \& Johnson, W. (1983). Exporting: Does sales volume make a difference?

Journal of International Business Studies, Spring/Summer, 147-153.

Daniels, J. D \& Goyburo, J. (1976). The exporter-non-exporter interface: A search for variables.

Foreign Trade Review, 3, 258-282

Das, M. (1994). Successful and unsuccessful exporters from developing countries: Some preliminary findings. European Journal of Marketing, 28(12), 19-34.

Dhanaraj, C. \& Beamish, P.W. (2003). A resource-based approach to the study of export performance. Journal of Small Business Management, 41(3), 242-61.

Dichtl, E., Köglmayr, H. G. \& Müller, S. (1990). International orientation as a precondition for export success. Journal of International Business Studies, 21(1), 23- 40.

Grant, R.M. (1991). The resource-based theory of competitive advantage: Implications from strategy formulation. California Management Review, 33, 114-135

Gujarati, D.N. (2003). Basic Econometrics, 4th Edition. New York: McGraw Hill.

Hall, G \& Tú, C. (2004). Internationalization and size, age and profitability in the United Kingdom. In Dana L-P (Ed). Handbook of Research on International Entrepreneurship (pp 596-613). Cheltenham: Edward Elgar.

Hymer, S. H. (1976). The international operations of national firms: A study of foreign direct investment. Cambridge, Mass: MIT Press

Itami, H. (1987). Mobilizing invisible assets. Cambridge, MA: Harvard University Press

Johanson, J \& Vahlne, J. E. (1977). The internationalization in industrial systems: A network approach In N. Hood \& J. E. Vahlne (Eds). Strategies in Global Competition (pp 287- 314). London: Croom Helm

Johanson, J. \& Vahlne, J. E. (1990). The mechanism of internationalization. International Marketing Review, 7(4), 11-24.

Johanson, J. \& Wiedersheim-Paul, F. (1975). The internationalization of the firm-four Swedish 
cases. Journal of Management Studies, 12(3), 305-322.

Jones, M.V. \& Crick, D. (2004). Internationalizing high-technology-based UK firms' information gathering activities. Journal of Small Business and Enterprise Development. 11(1) 84-94.

Jovanovic, B. (1982). Selection and evolution of industry. Econometrica, 50(3), 649-670.

Katsikeas, C. S. \& Piercy, N. F. (1993). Long-term export stimuli and firm characteristics in European LDC. Journal of International Marketing, 1(3), 23-47.

Keng, K. A. \& Jiuan, T. S. (1989). Differences between small and medium sized exporting and non-exporting firms: Nature or nurture. International Marketing Review, 6(4), 27-40.

Knight, G. A. \& Cavusgil, S. T. (2004). Innovation, organizational capabilities, and the born global firm. Journal of International Business Studies, 35(2), 124-141.

Kumar, N. \& Siddharthan, N. S. (1994). Technology, firm size and export behavior in developing countries: The case of Indian enterprise. Journal of Development Studies, 24, 288-309.

Leonidou, L. C. \& Katsikeas, C. S. (1996). The export development process: An integrative review of empirical models. Journal of International Business Studies, 27(3), 517-551.

Lipparini, A. \& Lorenzo, G. (1999). The leveraging of interfirm relationship as a distinctive organizational capability: A longitudinal study. Strategic Management Journal, 20, 317- 338.

López Rodríguez, J. \& López-Rodríguez, J. (2005). Technological and export behavior: A resourcebased view approach. Spain: Elsevier Ltd.

Mehran, J \& Moini, A. H. (1999). Firms' export behaviour. American Business Review, 17(1), 86-93.

Miesenbock, K. J. (1988). Small business and exporting: A literature review. International Small Business Journal, 6(2), 42-61.

Mittelstaedt, J. D., Harben, G. N.\& Ward, W. A. (2003). How small is too small? Firm size as a barrier to exporting from the United States. Journal of Small Business Management, 41(1), 6884.

Moen, O. (1999). The Relationship between firm size, competitive advantages export performance revisited. International Small Business Journal, 18 (1), 53-72.

Moen, O. \& Servias, P. (2002). Born global or gradual global? Examining the behaviour of small and medium-sized enterprises. Journal of International Marketing, 10(3), 49-72.

Nicholls, J.A.F., Lyn-Cook, M. \& Roslow, S. (1989). Strategies for export marketing of nontraditional products. International Marketing Review, 6(4), 58- 72.

Obben, J. \& Magagula, P. (2003). Firm and managerial determinants of the export propensity of small and medium-sized enterprises in Swaziland. International Small Business Journal, 21(1), 73- 89.

Oviatt, B. M. \& McDougall, P.P. (1994). Toward a theory of international new ventures. Journal of International Business Studies, 25(1) 45- 64.

Penrose, E. (1980). The theory of the growth of the firm (2nd Edition). Oxford: Basil Blackwell Publisher.

Philp, N. E. (1998). The export propensity of the very small enterprise (VSE). International Small Business Journal, 16, 79-93.

Pope, R. A. (2002). Why small firms export: Another look. Journal of Small Business Management, $40(1), 17-26$.

Porter, M. E. (1990). The competitive advantage of nations. New York: The Free Press. Roper, S. \& Love, J. (2002). Innovation and export performance: Evidence from the UK and

German manufacturing plants. Research Policy, 31, 1087-1102.

Reid, S. (1986). Is technology linked with export performance in small firms. In H. Hubner (Ed.), 
The Art and Science of Innovation Management (pp 273-283). Amsterdam: Elsevier Science. Reid, S. D. (1981). The decision-maker and export entry and expansion. Journal of International Business Studies, 12(2), 101- 112

Rhee, H.J. (2002). An exploratory examination of propensity and performance in new venture internationalization. New England Journal of Entrepreneurship, 5(1), $51-66$.

Rialp A., Rialp, J. \& Knight, G. A. (2005). The phenomenon of international new ventures, global start-ups and born-globals: What do we know after a decade (1993-2002) of exhaustive scientific inquiry? International Business Review, 14, 147-166.

Rodriguez, J. L. \& Rodriguez, R. M. G. (2005). Technology and export behaviour: A resourcebased view approach. International Business Review, 14(5), 539-557.

STATIN (2010), "External Trade", Kingston: Jamaica

Stimchcombe, A. L. (1965). Social structure of organization. In J.M. March (Ed.), Handbook of Organization (pp142-193). Chicago: Rand McNally Publishers.

Tseng, C. H., P. S. Tansuhaj \& J. Rose (2004). Are strategic assets contributions or constraints for smes to go international? An empirical study of the US manufacturing sector. Journal of American Academy of Business, 5(1-2), 246-254.

Tybjee, T. T. (1994). Internationalisation of high tech firms: Initial vs. extended involvement.

Journal of Global Marketing, 7(4), 59-78.

Vernon R. (1966). International investment and international trade in the product cycle. The Quarterly Journal of Economics, 2, 190-207.

Welch, Lawrence S. \& F. Weidersheim-Paul (1980). Initial exports - a marketing failure. Journal of Management Studies, (October) 17.

Whitey, J. J. (1980). Differences between exporters and non-exporters: Some hypotheses concerning small manufacturing business. American Journal of Small Business, 4, 29- 37.

Williams, D. A. (2007). Competitiveness of small enterprises: Insights from a developing economy. The Round Table, 96, 390, 347-363.

Williams, D. A. (2009). Understanding exporting in the small and micro enterprise (pp 1-183).

New York: Nova Science Publishers.

Williams, J. E. M. \& I. Chaston (2004). Links between the linguistic ability and international experience of export managers and their export marketing intelligence behaviour. International Small Business Journal, 22(5), 461-82.

Wilmore, L. (1992). Transnationals and foreign trade: Evidence from Brazil. Journal of Development Studies, 28, 314-335.

Yaprak, A. (1985). An empirical study of the differences between small exporting and nonexporting US firms. International Marketing Review, Summer, 2(2), 72- 83. 